\title{
Factors Affecting Loading and Unloading Productivity: A Case Study of PT. Tangguh Samudera Jaya
}

\author{
$1^{\text {st }}$ Hartati M. Pakpahan \\ Department of Transportation \\ Management \\ Sekolah Tinggi Manajemen Logistik \\ Indonesia \\ Bandung, Indonesia \\ medipakpahan@gmail.com
}

\author{
$2^{\text {nd }}$ Syafrianita \\ Department of Transportation \\ Management \\ Sekolah Tinggi Manajemen Logistik \\ Indonesia \\ Bandung, Indonesia \\ rianitashine@gmail.com
}

\author{
$3^{\text {rd }}$ Lea Salsa Shania \\ Department of Transportation \\ Management \\ Sekolah Tinggi Manajemen Logistik \\ Indonesia \\ Bandung, Indonesia \\ salsashanialea@gmail.com
}

\begin{abstract}
PT. Tangguh Samudera Jaya is a stevedoring company which operates the wharf 303, 304, and 305 at Terminal 3 in Tanjung Priok Port. Terminal 3 is predominantly serving international container stevedoring and small portions of domestic containers. Every time a vessel berths at Terminal 3 Tanjung Priok Port, especially at the wharf 303,304 , and 305, there is a decrease in the productivity of loading and unloading, which causes Key Performance Indicators (KPI) that company set can't be achieved. Therefore, this study uses the method of Multiple Linear Regression Analysis and Stepwise Regression, to determine the effect of loading and unloading time at the wharfs, loading and unloading time in a container yard, truck cycle time, and the number of ganks on productivity of loading and unloading and identifying the variables that have the greatest influence on loading and unloading productivity at the port. It was found that the independent variables can explain the dependent variable which is the loading and unloading productivity with a value of $99.9 \%$ while $1 \%$ is found in other variables besides the variables mentioned in this study. Overall or partially the independent variables significantly influence the loading and unloading productivity, and the variable that has the greatest influence on the loading and unloading productivity is loading and unloading time at wharfs.
\end{abstract}

Keywords-loading and unloading productivity, Box Container Hour (B/C/H), Multiple Linear Regression Analysis, Stepwise Regression

\section{INTRODUCTION}

Tanjung Priok Port is a major national and international port that serves as a gateway for national and international economic connectivity that serves as the backbone of national development, with a total volume of freights $60 \%$ to and from Indonesia. Tanjung Priok Port also has such an important position in the national transportation and logistics system that demands the Tanjung Priok Port on an ongoing basis must be able to facilitate Indonesia's economic and trade activities, and in the end it is expected that Tanjung Priok Port can encourage the national trade and industry sector to face international free trade.

PT. Tangguh Samudera Jaya is a stevedoring company which operates wharf 303, 304, and 305 at Terminal 3 in Tanjung Priok Port [1]. Priok Terminal 3 is predominantly serving international container stevedoring and a small portion of domestic containers. Stevedoring Company is one of the organizations in port activities that handles the loading and unloading of vessels, and oversees the work of loading and unloading labor.

During the last few months, there has been a decrease in the loading and unloading productivity at wharf 303, 304, 305 which are operated by PT. Tangguh Samudera Jaya [2], where the loading and unloading productivity is below the standard set by the company which is 20 boxes/ containers/ hour.

TABLE 1. LOADING AND UNLOAdING PRODUCTIVITy (B/C/H) IN JULY, AUGUST, SEPTEMBER 2018 AT TERMINAL 3 OF TANJUNG PRIOK PORT

\begin{tabular}{|c|r|c|c|c|c|}
\hline \multicolumn{1}{|c|}{ JULI } & \multicolumn{2}{|c|}{ AGUSTUS } & \multicolumn{2}{c|}{ SEPTEMBER } \\
\hline VESSEL & $\mathbf{B} / \mathbf{C} / \mathbf{H}$ & VESSEL & B/C/H & VESSEL & B/C/H \\
\hline CTP GOLDEN & 16.24 & SENDANG MAS & 20.07 & JONATHAN SWIFT & 10.74 \\
\hline CARPENTERS SIRIUS & 10.08 & ST GREEN & 17.94 & ST GREEN & 15.56 \\
\hline SENDANG MAS & 18.5 & ALS JUVENTUS & 12.65 & JOHAN FORTUNE & 29.23 \\
\hline ST GREEN & 13.42 & CTP HONOUR & 17.79 & ALS APOLLO & 11.93 \\
\hline CTP DELTA & 15.84 & SEGARA MAS & 18.47 & SEGARA MAS & 16.04 \\
\hline SMILEY LADY & 12.13 & PUTNAM & 22.13 & CTP GOLDEN & 27.05 \\
\hline SEGARA MAS & 17.31 & CTP GOLDEN & 17.26 & ISLAND CHIEF & 18.27 \\
\hline CTP FORTUNE & 14.79 & BAVARIA & 13.94 & MAERSK ABERDEEN & 16.64 \\
\hline CTP GOLDEN & 11.91 & CTP DELTA & 17.32 & CTP INNOVATION & 25.00 \\
\hline
\end{tabular}




\begin{tabular}{|c|r|c|r|r|r|}
\hline \multicolumn{1}{|c|}{ JULI } & \multicolumn{2}{c|}{ AGUSTUS } & \multicolumn{2}{c|}{ SEPTEMBER } \\
\hline VESSEL & B/C/H & VESSEL & B/C/H & \multicolumn{1}{c|}{ VESSEL } & B/C/H \\
\hline CTP INNOVATION & 25.38 & SMILEY LADY & 11.11 & HOLSATIA & 11.06 \\
\hline SENDANG MAS & 17.17 & GH MISTRAL & 18.54 & CTP DELTA & 18.88 \\
\hline CTP DELTA & 17.34 & CARPENTERS SIRIUS & 10.47 & GH MISTRAL & 18.83 \\
\hline ST GREEN & 13.81 & ST GREEN & 15.19 & SHAOSHING & 6.76 \\
\hline CTP FORTUNE & 11.89 & SEGARA MAS & 17.83 & ST GREEN & 14.87 \\
\hline SEGARA MAS & 15.47 & CTP HONOUR & 20.07 & SZECHUEN & 15.51 \\
\hline SHAOSHING & 12.79 & HANNE DANICA & 1.84 & ALS JUVENTUS & 15.21 \\
\hline FLORA DELMAS & 9.73 & MAERSK ABERDEEN & 13.22 & CTP GOLDEN & 20.92 \\
\hline CTP GOLDEN & 18.83 & CTP GOLDEN & 19.45 & SEGARA MAS & 18.04 \\
\hline & & CTP DELTA & 16.08 & SMILEY LADY & 14.00 \\
\hline & & SINGAPORE BRIDGE & 15.44 & CTP HONOUR & 15.66 \\
\hline & & GH MISTRAL & 19.09 & CTP INNOVATION & 16.95 \\
\hline & & FLORA DELMAS & 14.46 & GH MISTRAL & 16.19 \\
\hline & & & & CTP DELTA & 19.35 \\
\hline & & & & MAERSK ABERDEEN & 17.85 \\
\hline & & & & ST GREEN & 13.62 \\
\hline
\end{tabular}

Source: Terminal Departure Report (TDR) of Terminal 3 of Tanjung Priok Port

In a previous study conducted by Gunawan [3], using factors that allegedly affected the loading and unloading process at PT. Pelayaran Meratus which are the number of ganks, full empty ratio, total container weights, loading/ unloading equipment, and loading/ unloading time. It was concluded that the container weight factor is the most influential factor on all ships.

This study uses four factors that are suspected to influence loading and unloading productivity, which are loading and unloading time at wharf (using Harbour Mobile Crane and Quay Container Crane), loading and unloading time in Container Yard (using Rubber Tyred Gantry and Reach Stacker), truck cycle time, and the number of ganks.

\section{METHODS}

The data used in this study are primary data and secondary data. The primary data obtained is by conducting field observations namely counting loading and unloading time on each equipment used in wharf (Harbour Mobile Crane/ HMC and Quay Container Crane/ QCC) and in container yard (Rubber Tire Gantry/ RTG and Reach Stacker/ RS), counting the truck cycle time in the cargodoring process.

For secondary data taken directly from PT. Tangguh Samudera Jaya is the data of vessels in July, August, and September 2018, namely the TDR (Terminal Departure Report) data to find out information about berth and the realization of productivity of loading and unloading, Crane Sequence data to find out reports of the process of loading and unloading of vessels.

For the input variables (independent variables) used, they are:

1. Variable X1: loading and unloading time at the wharfs (HMC, QCC)

2. Variable X2: loading and unloading time in container yard (RTG, RS)

3. Variable X3: truck cycle time

4. Variable X4: number of ganks

A. Ordinary Least Square (OLS) Test

\section{Normality Test}

Normality test is conducted to determine whether the residual value is normally distributed or not.

According to Gendro Wijoyo [4] for testing normality with One Sample Kolmogrof-Smirnov can be stated normally distributed if the significance is greater than 0.05 $(5 \%)$.

\section{Multicollinearity Test}

According to Imam Ghozali [5] "Multicollinearity test aims to test whether the regression model found a correlation between independent variables (independent)." A good regression model should not occur the correlation between independent variables. If the independent variables are correlated with each other, then these variables are not orthogonal.

\section{Autocorrelation Test}

According to Imam Ghozali [5] Autocorrelation test aims to test whether in the linear regression model there is a correlation between the error of the intruder in the period $\mathrm{t}$ with an error in the period $\mathrm{t}-1$ (previous).

\section{Heteroskedacity Test}

Based on the explanation of Imam Ghozali [5], "The heteroskedacity test aims to test whether in the regression model there is an inequality of variance and other residuals".

\section{B. Factor Analysis}

The main purpose of factor analysis is to describe the structure of relationships among many variables in the form factors or latent variables or variable formations. Factors that formed a random quantity (random quantities) that previously could not be observed or measured or determined directly.

\section{Multiple Regression Analysis}

Multiple Regression Analysis is used because the regression model used consists of one dependent variable and has more than one independent variable to find the correlation between the dependent variable and the 
independent variable, and to find out the regression model used in the study are as follows:

$\mathrm{Y}=\beta+\beta_{1} \mathrm{X}_{1}+\ldots . .+\beta_{\mathrm{n}} \mathrm{X}_{\mathrm{n}}+\mathrm{e}$

\section{1. $t$-Test}

T-test aims to find out whether or not there is a partial effect (alone) given the independent variable $(x)$ to the dependent variable (y). On the basis of decision making: If the Sig value $<0.05$ or $t$ arithmetic $>t$ table then there is the influence of the independent variable $(\mathrm{x})$ on the dependent variable $(y)$, and if the Sig value $>0.05$ or $t$ arithmetic $<\mathrm{t}$ table then there is no influence of the independent variable ( $\mathrm{x})$ with respect to the dependent variable $(\mathrm{y})$.

\section{F-Test}

The $\mathrm{F}$ test aims to determine whether there is a simultaneous influence (together) given the independent variable $(\mathrm{x})$ on the dependent variable $(\mathrm{y})$. On the basis of decision making: If the value of Sig. $<0.05$ or F arithmetic $>$ $\mathrm{F}$ table then there is a simultaneous influence of the independent variable $(\mathrm{x})$ on the dependent variable $(\mathrm{y})$, and if the Sig. $>0.05$ or F arithmetic $<\mathrm{F}$ table then there is no simultaneous effect of the independent variable $(\mathrm{x})$ on the dependent variable (y).

\section{Stepwise}

Regression analysis using the stepwise method is used to find out which statement of the independent variable most influences the dependent variable. Stepwise regression involves two types of processes namely forward selection and backward elimination. The incoming variable is the variable that has the highest and significant correlation with the dependent variable, after certain variables enter the model, the other variables in the model are evaluated, if there are insignificant variables, the variable is excluded.

\section{RESULTS AND DISCUSSIONS}

\section{A. Loading and Unloading Time at Wharfs}

The loading and unloading equipments at wharfs are HMC and QCC by taking sample from 56 containers from each vessel that berthed. The following is the average time data from all loading and unloading processes on each vessel.

\begin{tabular}{|c|c|c|c|c|c|}
\hline No & Vessel & Time & No & Vessel & Time \\
\hline 1 & CTP GOLDEN & 140.40 & 34 & HANNE DANICA & 145.80 \\
\hline 2 & CARPENTERS SIRIUS & 141.60 & 35 & MAERSK ABERDEEN & 139.80 \\
\hline 3 & SENDANG MAS & 145.20 & 36 & CTP GOLDEN & 134.40 \\
\hline 4 & ST GREEN & 133.20 & 37 & CTP DELTA & 151.80 \\
\hline 5 & CTP DELTA & 154.80 & 38 & SINGAPORE BRIDGE & 141.60 \\
\hline 6 & SMILEY LADY & 139.80 & 39 & GH MISTRAL & 154.20 \\
\hline 7 & SEGARA MAS & 140.40 & 40 & FLORA DELMAS & 137.40 \\
\hline 8 & CTP FORTUNE & 153.60 & 41 & JONATHAN SWIFT & 183.60 \\
\hline 9 & CTP GOLDEN & 149.40 & 42 & ST GREEN & 151.80 \\
\hline 10 & CTP INNOVATION & 188.40 & 43 & JOHAN FORTUNE & 144.60 \\
\hline 11 & SENDANG MAS & 137.40 & 44 & ALS APOLLO & 188.40 \\
\hline 12 & CTP DELTA & 183.60 & 45 & SEGARA MAS & 139.80 \\
\hline 13 & ST GREEN & 151.80 & 46 & CTP GOLDEN & 145.80 \\
\hline 14 & CTP FORTUNE & 144.60 & 47 & ISLAND CHIEF & 139.80 \\
\hline 15 & SEGARA MAS & 188.40 & 48 & MAERSK ABERDEEN & 134.40 \\
\hline 16 & SHAOSHING & 139.80 & 49 & CTP INNOVATION & 151.80 \\
\hline 17 & FLORA DELMAS & 145.80 & 50 & HOLSATIA & 141.60 \\
\hline 18 & CTP GOLDEN & 139.80 & 51 & CTP DELTA & 154.20 \\
\hline 19 & SENDANG MAS & 134.40 & 52 & GH MISTRAL & 139.80 \\
\hline 20 & ST GREEN & 151.80 & 53 & SHAOSHING & 145.80 \\
\hline 21 & ALS JUVENTUS & 141.60 & 54 & ST GREEN & 139.80 \\
\hline 22 & CTP HONOUR & 154.20 & 55 & SZECHUEN & 134.40 \\
\hline 23 & SEGARA MAS & 139.80 & 56 & ALS JUVENTUS & 151.80 \\
\hline 24 & PUTNAM & 140.40 & 57 & CTP GOLDEN & 141.60 \\
\hline 25 & CTP GOLDEN & 153.60 & 58 & SEGARA MAS & 154.20 \\
\hline 26 & BAVARIA & 149.40 & 59 & SMILEY LADY & 151.80 \\
\hline 27 & CTP DELTA & 188.40 & 60 & CTP HONOUR & 144.60 \\
\hline 28 & SMILEY LADY & 137.40 & 61 & CTP INNOVATION & 188.40 \\
\hline 29 & GH MISTRAL & 183.60 & 62 & GH MISTRAL & 139.80 \\
\hline 30 & CARPENTERS SIRIUS & 151.80 & 63 & CTP DELTA & 145.80 \\
\hline 31 & ST GREEN & 144.60 & 64 & MAERSK ABERDEEN & 139.80 \\
\hline 32 & SEGARA MAS & 188.40 & 65 & ST GREEN & 144.60 \\
\hline 33 & CTP HONOUR & 139.80 & & & \\
\hline
\end{tabular}

B. Loading and Unloading Time at Container Yard

The loading and unloading tool at CY is RTG and RS by taking sample from 56 containers in the loading and unloading process to/ from the chassis truck for each vessel that berthed. 
TABLE 3. LOADING AND UNLOADING TIME (SECONDS) AT CONTAINER YARD

\begin{tabular}{|c|c|c|c|c|c|}
\hline No & Vessel & Time & No & Vessel & Time \\
\hline 1 & CTP GOLDEN & 198.00 & 34 & HANNE DANICA & 241.80 \\
\hline 2 & CARPENTERS SIRIUS & 144.00 & 35 & MAERSK ABERDEEN & 147.60 \\
\hline 3 & SENDANG MAS & 85.20 & 36 & CTP GOLDEN & 199.80 \\
\hline 4 & ST GREEN & 153.00 & 37 & CTP DELTA & 183.60 \\
\hline 5 & CTP DELTA & 138.00 & 38 & SINGAPORE BRIDGE & 195.60 \\
\hline 6 & SMILEY LADY & 132.00 & 39 & GH MISTRAL & 195.00 \\
\hline 7 & SEGARA MAS & 81.00 & 40 & FLORA DELMAS & 141.60 \\
\hline 8 & CTP FORTUNE & 154.20 & 41 & JONATHAN SWIFT & 87.60 \\
\hline 9 & CTP GOLDEN & 184.80 & 42 & ST GREEN & 88.20 \\
\hline 10 & CTP INNOVATION & 258.60 & 43 & JOHAN FORTUNE & 85.20 \\
\hline 11 & SENDANG MAS & 141.60 & 44 & ALS APOLLO & 138.00 \\
\hline 12 & CTP DELTA & 87.60 & 45 & SEGARA MAS & 138.00 \\
\hline 13 & ST GREEN & 88.20 & 46 & CTP GOLDEN & 241.80 \\
\hline 14 & CTP FORTUNE & 85.20 & 47 & ISLAND CHIEF & 147.60 \\
\hline 15 & SEGARA MAS & 138.00 & 48 & MAERSK ABERDEEN & 199.80 \\
\hline 16 & SHAOSHING & 138.00 & 49 & CTP INNOVATION & 183.60 \\
\hline 17 & FLORA DELMAS & 241.80 & 50 & HOLSATIA & 195.60 \\
\hline 18 & CTP GOLDEN & 147.60 & 51 & CTP DELTA & 195.00 \\
\hline 19 & SENDANG MAS & 199.80 & 52 & GH MISTRAL & 138.00 \\
\hline 20 & ST GREEN & 183.60 & 53 & SHAOSHING & 241.80 \\
\hline 21 & ALS JUVENTUS & 195.60 & 54 & ST GREEN & 147.60 \\
\hline 22 & CTP HONOUR & 195.00 & 55 & SZECHUEN & 199.80 \\
\hline 23 & SEGARA MAS & 132.00 & 56 & ALS JUVENTUS & 183.60 \\
\hline 24 & PUTNAM & 81.00 & 57 & CTP GOLDEN & 195.60 \\
\hline 25 & CTP GOLDEN & 154.20 & 58 & SEGARA MAS & 195.00 \\
\hline 26 & BAVARIA & 184.80 & 59 & SMILEY LADY & 88.20 \\
\hline 27 & CTP DELTA & 258.60 & 60 & CTP HONOUR & 85.20 \\
\hline 28 & SMILEY LADY & 141.60 & 61 & CTP INNOVATION & 138.00 \\
\hline 29 & GH MISTRAL & 87.60 & 62 & GH MISTRAL & 138.00 \\
\hline 30 & CARPENTERS SIRIUS & 88.20 & 63 & CTP DELTA & 241.80 \\
\hline 31 & ST GREEN & 85.20 & 64 & MAERSK ABERDEEN & 147.60 \\
\hline 32 & SEGARA MAS & 138.00 & 65 & ST GREEN & 85.20 \\
\hline 33 & CTP HONOUR & 138.00 & & & \\
\hline
\end{tabular}

\section{Truck Cycle Time}

Trucks used are trucks owned by PT. Samudera Perdana is a type of hino and volvo truck, by taking a sample of 19 rounds from each vessel that is berthed to see when the trucking turns on the loading and unloading process.

TABLE 4. TRUCK CYCLE TIME (SECONDS)

\begin{tabular}{|c|c|c|c|c|c|}
\hline No & Vessel & Time & No & Vessel & Time \\
\hline 1 & CTP GOLDEN & 964.80 & 34 & HANNE DANICA & 973.20 \\
\hline 2 & CARPENTERS SIRIUS & 1450.20 & 35 & MAERSK ABERDEEN & 904.20 \\
\hline 3 & SENDANG MAS & 621.60 & 36 & CTP GOLDEN & 991.80 \\
\hline 4 & ST GREEN & 484.20 & 37 & CTP DELTA & 870.60 \\
\hline 5 & CTP DELTA & 690.00 & 38 & SINGAPORE BRIDGE & 806.40 \\
\hline 6 & SMILEY LADY & 486.00 & 39 & GH MISTRAL & 784.80 \\
\hline 7 & SEGARA MAS & 602.40 & 40 & FLORA DELMAS & 933.60 \\
\hline 8 & CTP FORTUNE & 841.20 & 41 & JONATHAN SWIFT & 982.20 \\
\hline 9 & CTP GOLDEN & 690.60 & 42 & ST GREEN & 1215.60 \\
\hline 10 & CTP INNOVATION & 688.20 & 43 & JOHAN FORTUNE & 724.80 \\
\hline 11 & SENDANG MAS & 933.60 & 44 & ALS APOLLO & 488.40 \\
\hline 12 & CTP DELTA & 982.20 & 45 & SEGARA MAS & 322.80 \\
\hline 13 & ST GREEN & 1215.60 & 46 & CTP GOLDEN & 973.20 \\
\hline 14 & CTP FORTUNE & 724.80 & 47 & ISLAND CHIEF & 904.20 \\
\hline 15 & SEGARA MAS & 488.40 & 48 & MAERSK ABERDEEN & 991.80 \\
\hline 16 & SHAOSHING & 322.80 & 49 & CTP INNOVATION & 870.60 \\
\hline 17 & FLORA DELMAS & 973.20 & 50 & HOLSATIA & 806.40 \\
\hline 18 & CTP GOLDEN & 904.20 & 51 & CTP DELTA & 784.80 \\
\hline 19 & SENDANG MAS & 991.80 & 52 & GH MISTRAL & 322.80 \\
\hline 20 & ST GREEN & 870.60 & 53 & SHAOSHING & 973.20 \\
\hline 21 & ALS JUVENTUS & 806.40 & 54 & ST GREEN & 904.20 \\
\hline
\end{tabular}




\begin{tabular}{|c|c|c|c|c|c|}
\hline No & Vessel & Time & No & Vessel & Time \\
\hline 22 & CTP HONOUR & 784.80 & 55 & SZECHUEN & 991.80 \\
\hline 23 & SEGARA MAS & 486.00 & 56 & ALS JUVENTUS & 870.60 \\
\hline 24 & PUTNAM & 602.40 & 57 & CTP GOLDEN & 806.40 \\
\hline 25 & CTP GOLDEN & 841.20 & 58 & SEGARA MAS & 784.80 \\
\hline 26 & BAVARIA & 690.60 & 59 & SMILEY LADY & 1215.60 \\
\hline 27 & CTP DELTA & 688.20 & 60 & CTP HONOUR & 724.80 \\
\hline 28 & SMILEY LADY & 933.60 & 61 & CTP INNOVATION & 488.40 \\
\hline 29 & GH MISTRAL & 982.20 & 62 & GH MISTRAL & 322.80 \\
\hline 30 & CARPENTERS SIRIUS & 1215.60 & 63 & CTP DELTA & 973.20 \\
\hline 31 & ST GREEN & 724.80 & 64 & MAERSK ABERDEEN & 904.20 \\
\hline 32 & SEGARA MAS & 488.40 & 65 & ST GREEN & 724.80 \\
\hline 33 & CTP HONOUR & 322.80 & & & \\
\hline
\end{tabular}

\section{Number of Ganks}

Number of ganks is number workers in one work team.

TABLE 5. NUMBER OF GANKS

\begin{tabular}{|c|c|c|c|c|c|}
\hline \multicolumn{1}{|c}{ JULI } & \multicolumn{2}{c|}{ AGUSTUS } & \multicolumn{2}{c|}{ SEPTEMBER } \\
\hline VESSEL & GANK & VESSEL & GANK & VESSEL & GANK \\
\hline CTP GOLDEN & 2.00 & SENDANG MAS & 4.00 & JONATHAN SWIFT & 1.00 \\
\hline CARPENTERS SIRIUS & 2.00 & ST GREEN & 3.00 & ST GREEN & 3.00 \\
\hline SENDANG MAS & 4.00 & ALS JUVENTUS & 1.00 & JOHAN FORTUNE & 1.00 \\
\hline ST GREEN & 4.00 & CTP HONOUR & 5.00 & ALS APOLLO & 1.00 \\
\hline CTP DELTA & 2.00 & SEGARA MAS & 3.00 & SEGARA MAS & 3.00 \\
\hline SMILEY LADY & 1.00 & PUTNAM & 1.00 & CTP GOLDEN & 1.00 \\
\hline SEGARA MAS & 4.00 & CTP GOLDEN & 3.00 & ISLAND CHIEF & 3.00 \\
\hline CTP FORTUNE & 3.00 & BAVARIA & 1.00 & MAERSK ABERDEEN & 3.00 \\
\hline CTP GOLDEN & 4.00 & CTP DELTA & 1.00 & CTP INNOVATION & 1.00 \\
\hline CTP INNOVATION & 1.00 & SMILEY LADY & 1.00 & HOLSATIA & 1.00 \\
\hline SENDANG MAS & 4.00 & GH MISTRAL & 3.00 & CTP DELTA & 2.00 \\
\hline CTP DELTA & 1.00 & CARPENTERS SIRIUS & 2.00 & GH MISTRAL & 2.00 \\
\hline ST GREEN & 4.00 & ST GREEN & 4.00 & SHAOSHING & 3.00 \\
\hline CTP FORTUNE & 3.00 & SEGARA MAS & 3.00 & ST GREEN & 3.00 \\
\hline SEGARA MAS & 4.00 & CTP HONOUR & 2.00 & SZECHUEN & 2.00 \\
\hline SHAOSHING & 2.00 & HANNE DANICA & 2.00 & ALS JUVENTUS & 1.00 \\
\hline FLORA DELMAS & 2.00 & MAERSK ABERDEEN & 3.00 & CTP GOLDEN & 2.00 \\
\hline CTP GOLDEN & 3.00 & CTP GOLDEN & 2.00 & SEGARA MAS & 3.00 \\
\hline & & CTP DELTA & 2.00 & SMILEY LADY & 2.00 \\
\hline & & SINGAPORE BRIDGE & 1.00 & CTP HONOUR & 2.00 \\
\hline & & GH MISTRAL & 3.00 & CTP INNOVATION & 1.00 \\
\hline & & FLORA DELMAS & 1.00 & GH MISTRAL & 2.00 \\
\hline & & & CTP DELTA & 2.00 \\
\hline & & & & MAERSK ABERDEEN & 2.00 \\
\hline
\end{tabular}

\section{E. Ordinary Least Square (OLS) Test Result}

There are some test are carried out in OLS test:

1. normality test

2. multicollinearity test

3. autocorrelation test

4. heteroskedacity test

TABLE 6. NORMALITY TEST RESUlT

\begin{tabular}{|l|c|c|l|}
\hline Model & Asymp.Sig (2-tailed) & Criteria & Conclusion \\
\hline $\begin{array}{l}\text { Undstandardized } \\
\text { Residual }\end{array}$ & 0,200 & $>0,05$ & normal distribution \\
\hline
\end{tabular}

TABLE 7. MUlticollineARITY TEST RESUlT

\begin{tabular}{|c|c|c|c|c|}
\hline Variable & Tolerance & VIF & Criteria & Conclusion \\
\hline $\begin{array}{c}\text { loading and unloading time at the wharfs } \\
\text { (HMC, QCC) }\end{array}$ & 0,958 & 1,044 & $\begin{array}{c}\text { Tolerance } \geq 0,1 \\
\text { VIF } \leq 10\end{array}$ & $\begin{array}{c}\text { No Multicollinearity } \\
\text { Occurs }\end{array}$ \\
\cline { 1 - 2 } $\begin{array}{c}\text { loading and unloading time in container } \\
\text { yard (RTG, RS) }\end{array}$ & 0,956 & 1,046 & \\
\hline
\end{tabular}




\begin{tabular}{|c|c|c|c|c|}
\hline Variable & Tolerance & VIF & Criteria & Conclusion \\
\hline truck cycle time & 0,980 & 1,020 & & \\
\hline number of ganks & 0,937 & 1,067 & & \\
\hline
\end{tabular}

TABLE 8. AUTOCORRELATION TEST RESULT

\begin{tabular}{ccccc}
\hline DW & DL & DU & 4-DL & 4-DU \\
\hline 2,197 & 1,4758 & 1,7319 & 2,5242 & 2,2681 \\
\hline
\end{tabular}

The results of data processing show that there is no autocorrelation in the regression model because the Durbin
Watson (DW) value is between the Durbin Upper (DU) value and the 4-Durbin Upper (DU) value.

TABLE 9. Heteroskedacity Test Result

\begin{tabular}{|c|c|c|c|}
\hline Variable & Sig. & Criteria & Conclusion \\
\hline $\begin{array}{c}\text { loading and unloading time at the } \\
\text { wharfs (HMC, QCC) }\end{array}$ & 0,761 & $\geq 0,05$ & \\
\cline { 1 - 2 } $\begin{array}{c}\text { loading and unloading time in } \\
\text { container yard (RTG, RS) }\end{array}$ & 0,843 & & \\
\hline truck cycle time & 0,172 & & \\
\hline number of ganks & 0,666 & & \\
\hline
\end{tabular}

\section{F. Factor Analysis Result}

Initial Eigenvalues indicate the factors formed. If all the factors added together indicate the number of variables (i.e. $1,231+1,159+0,872+0,738=4$ variables $)$. Whereas the Extraction Sums of Squared Loadings section shows the number of variations or the number of factors that can be formed from 4 variables, where the requirement to be a factor is the Eigenvalue value must be greater than 1 . The Eigenvalue Component 1 value of 1.231 or more than 1 will be a factor of 1 and is able to explain $30.787 \%$ variation. While the Eigenvalue Component 2 value of 1.159 or more than 1 becomes a factor of 2 and is able to explain $59.752 \%$ variation.

TABLE 10. FACTOR ANALYSIS RESULT

\begin{tabular}{|c|l|l|l|l|l|l|}
\hline & \multicolumn{3}{|l|}{ Initial Eigenvalues } & \multicolumn{3}{l|}{ Extraction Sums of Squared Loadings } \\
\hline Component & Total & \% of Variance & Cumulative \% & Total & \% of Variance & Cumulative \% \\
\hline 1 & 1,231 & 30,787 & 30,787 & 1,231 & 30,787 & 30,787 \\
\hline 2 & 1,159 & 28,966 & 59,752 & 1,159 & 28,966 & 5,752 \\
\hline 3 & 0,872 & 21,801 & 81,554 & & & \\
\hline 4 & 0,738 & 18,446 & 100,000 & & & \\
\hline
\end{tabular}

The scree plot image also shows the number of factors formed, by looking at the value of component points that have an Eigenvalue> 1. From the images that have been obtained there are two component points that have an Eigenvalue> 1, it can be interpreted that there are two factors that can formed.

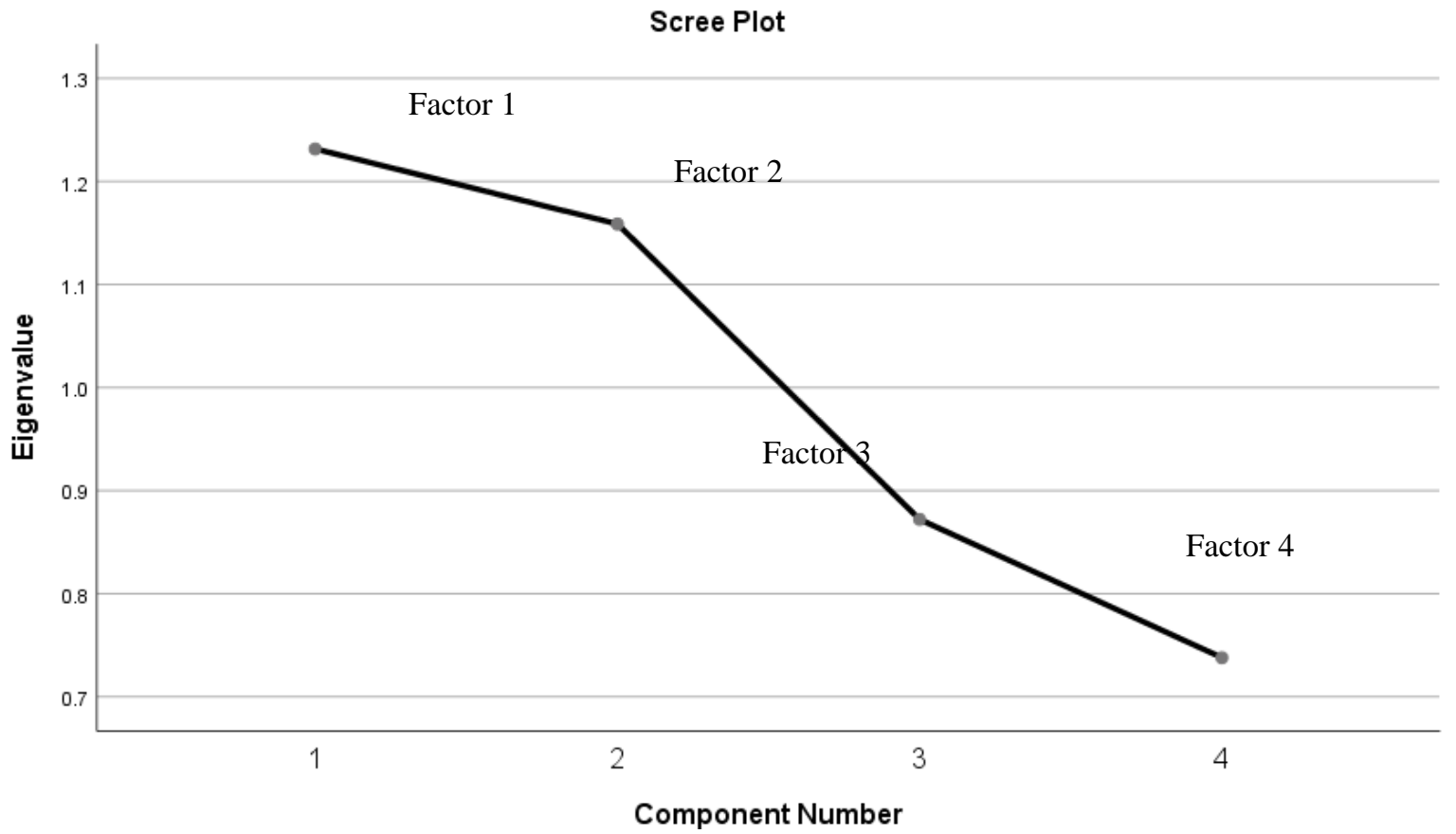


Fig 1. Scree Plot

\section{G. Multiple Regression Analysis Result}

Based on the regression analysis results using the stepwise method, it can be seen that the loading and unloading time at wharfs or the $\mathrm{X} 1$ variable have a statistical influence on the regression equation model with an X1 coefficient value of 0.107 and an R2 value of 0.999 . With the equation obtained, $\mathrm{Y}=0.005+0.107 \mathrm{X} 1$.

TABLE 11. MUlTIPLE REGRESSION ANALYSIS RESUlT

\begin{tabular}{|l|l|c|c|c|c|c|c|}
\hline Variable & Coefficients & R-Square & Adjusted R-Square & T Stat & Sig. t & F & Sig. F. \\
\hline Intercept & 0,005 & 0.999 & 0.999 & & & 24153.364 & 0.000 \\
\hline X1 & 0.107 & & & 0.531 & 0.597 & & \\
\hline
\end{tabular}

\section{CONCLUSIONS}

The variable that has the most influence on loading and unloading productivity is the loading and unloading time at wharfs variable. The slower the loading and unloading equipment (HMC and QCC) at wharfs will decrease the loading and unloading productivity. To increase the loading and unloading process time that has an affect on loading and unloading productivity, PT. Tangguh Samudera Jaya should pay more attention to the condition

\section{REFERENCES}

[1] PT Samudera Indonesia Tbk, "PT. Samudera Indonesia," 2018 [Online]. Available:

https://www.samudera.id/ptsamuderaindonesiatbk/id/2/layanank ami/8/8/55/46. [Diakses 18 April 2019].

[2] T. P. P. Terminal 3, "(TDR), Terminal Departure Report - Berth Planner," Terminal 3, Tanjung Priok Port, Jakarta, 2018.

[3] H. e. a. Gunawan, "Analisis Faktor-faktor yang Berpengaruh terhadap Produktivitas Bongkar Muat Kontainer di Dermaga of the loading and unloading equipment (QCC and HMC) especially in terms of maintenance or the company can add the equipment used so that the loading and unloading productivity can reach KPI which have been set. In addition, companies should pay attention to the human resources involved in the loading and unloading process, especially the crane operators (QCC and HMC), good human resources will make the performance better and the results of loading and unloading productivity will increase.

Berlian Surabaya (Studi Kasus PT. Pelayaran Meratus,” Widya Teknik, pp. 79-89, 2008.

[4] G. Wijoyo, Merancang Penelitian Bisnis dengan Alat Analisis SPSS 17.0 \& SmartPLS 2.0, Yogyakarta: STIM YKPN, edisi 1, 2011.

[5] I. Ghozali, Aplikasi Analisis Multivariate dengan Program IBM SPSS 23, Semarang: Badan Penerbit Universitas Diponegoro, 2016. 